\title{
The Once and Future Law of State Responsibility
}

\author{
By Martins Paparinskis ${ }^{*}$
}

\section{ABSTRACT}

The current (once) international law of state responsibility is shaped by the International Law Commission's Articles on responsibility of States for internationally wrongful acts, generally endorsed in state and judicial practice as consonant with custom. This Essay makes the case that the global pandemic and associated practice may affect foundational elements of the (future) law of state responsibility. It outlines the contours of systemic grain of possible developments by reference to the tension between bilateralism and community interests in international law.

\section{INTRODUCTION}

Can the COVID-19 global pandemic (Pandemic) affect foundational elements of the international legal order, in particular the generalist vocabulary of state responsibility? Two considerations frame the inquiry. On the one hand, the claim should not be lightly entertained that the Pandemic alters the foundations of international law. Plagues have been part of its social and legal fabric ${ }^{1}$ as relatable metaphors ${ }^{2}$ and normal subjects of incidental regulation since the classic texts. ${ }^{3}$ The general point is that the foundational layers of international law are remarkably stable, capable of accommodating fundamental shifts in politics and institutions. ${ }^{4}$ On the other hand, some shifts have indeed changed the foundations of the international legal order. World War I and Versailles gave international law a strong nudge toward multilateralism ${ }^{5}$ and a self-conception of normative completeness; ${ }^{6}$ World War II and San Francisco expanded the range of actors and specialist fields; ${ }^{7}$ decolonization remade

* Reader in Public International Law, University College London. Email: m.paparinskis@ucl.ac.uk. I am grateful to Christiane Ahlborn, Roger O'Keefe, and Meagan Wong for their insightful comments.

${ }^{1}$ An early writer on reprisals may have been a victim himself. R. Joseph Schork \& John P. McCall, A Lament on the Death of John of Legnano, 19 Studies Renaissance 180 (1972).

${ }^{2}$ Hugo Grotius, The Rights of War and Peace in Three Books: Wherein Are Explained, the Law of Nature and Nations, and the Principal Points Relating to Government 287, 298, 409, 499 (1738).

${ }^{3}$ Emmerich De Vattel, The Law of Nations or Principles of the Law of Nature, Applied to the Conduct and Affairs of Nations AND Sovereigns 180 (1872) ("if [a vessel in distress] is infected with the plague, the owner of the port [that it seeks to enter] may fire upon it and beat it off”).

${ }^{4}$ James Crawford, The Current Political Discourse Concerning International Law, 81 MoD. L. REv. 1, 2-6, 2122 (2018).

${ }^{5}$ Yves Daudet, 1919-2019, le flux du multilatéralisme, 403 ReCuEIL DEs Cours 17 (2017).

${ }^{6}$ Vaughan Lowe, The Politics of Law-Making, in The Role of LaW In InTERnational Politics: Essays IN InTERNATIONAL RELATIONS AND INTERNATIONAL LAW 207, 211-12 (Michael Byers ed., 2001).

${ }^{7}$ Reparation for Injuries Suffered in the Service of the United Nations, Advisory Opinion, 1949 ICJ Rep. 174, 17879 (Apr. 11); Reservations to the Convention on Genocide, Advisory Opinion, 1951 ICJ Rep. 15, 23 (May 28). 
the law of treaties ${ }^{8}$ and further strengthened community interests; ${ }^{9}$ and the end of the Cold War endorsed a shared conception of state responsibility, further recalibrating the law in a more multilateral direction. ${ }^{10}$ To be sure, international law is not (just) a discipline of crisis, ${ }^{11}$ and not every crisis will shake its foundations. But neither should the possibility be excluded that a global, universal, and urgent crisis of the Pandemic's quality could tilt them.

This Essay addresses the Pandemic and state responsibility, adopting the tension between bilateralism and communitarian considerations as its analytical perspective. ${ }^{12}$ It proceeds in three stages. Part II introduces the modern law of state responsibility, suggesting that the Pandemic has opened a lawmaking window for its change. Parts III and IV set out parallel arguments for its shift in, respectively, communitarian and bilateralist direction. The Essay makes two basic claims. First, the law of responsibility may be significantly affected by the Pandemic and reactions thereto by the international community. Secondly, whether this reading of the tea leaves of practice proves correct is ultimately less important than the changing terms of the inquiry. Discussion of state responsibility of the last two decades, mainly by reference to persuasiveness and application of the International Law Commission's (ILC) 2001 Articles on responsibility of States for internationally wrongful acts (ILC Articles), ${ }^{13}$ may be replaced by an examination of fundamental systemic issues of the kind last properly entertained at the turn of the century, ${ }^{14}$ in a legal order set to very different mood music. ${ }^{15}$

\section{The Once Law of State Responsibility}

Can the future of state responsibility hold anything but further reentrenchment of the ILC Articles through routine invocation by states and application by tribunals? The ILC Articles exercise a powerful influence over the international legal process. The UN General Assembly has repeatedly acknowledged their importance and usefulness, noting in 2019 "that a growing

${ }^{8}$ Matthew Craven, The Decolonization of International Law: State Succession and the Law of Treaties (2007)

${ }^{9}$ Bruno Simma, From Bilateralism to Community Interest in International Law, 250 R.C.A.D.I. 217, ch. I (1994).

${ }^{10}$ James Crawford, Multilateral Rights and Obligations in International Law, 319 R.C.A.D.I. 329, chs. IV-V (2006).

${ }^{11}$ Hilary Charlesworth, International Law: A Discipline of Crisis, 65 Mod. L. Rev. 377 (2002).

${ }^{12}$ E.g. Simma, supra note 9; Santiago Villalpando, L'émergence de la Communauté Internationale dans LA ResPOnSABILITÉ DES ETATS (2005); Crawford, Multilateral Rights, supra note 10; Santiago Villalpando, The Legal Dimension of the International Community: How Community Interests Are Protected in International Law, 21 Eur. J. INT'L L. 387 (2010); Giorgio Gaja, The Protection of General Interests in the International Community, 364 R.C.AD.I. 15 (2011); Pierre-Marie Dupuy, Back to the Future of a Multilateral Dimension of the Law of State Responsibility for Breaches of “Obligations Owed to International Community as a Whole," 23 EUR. J. INT'L L. 3871059 (2012).

${ }^{13}$ Int'l L. Comm'n, Articles on responsibility of States for internationally wrongful acts, 2 Y.B. INT'L L. Comm'n, pt. 2 (2001), UN Doc. A/CN.4/SER.A/2001/Add. 1 (Part 2) 26. E.g. Robert Sloane, On the Use and Abuse of Necessity in the Law of State Responsibility, 106 AJIL 447 (2012); Miles JACKSON, COMPLICITY IN International LaW (2015); Federica PaddeU, Justification and EXCUSE In InTERnational LaW (2018).

${ }^{14}$ Symposium: State Responsibility, 10 Eur. J. InT'L L. 339 (1999); Symposium: Assessing the Work of the International Law Commission on State Responsibility, 13 Eur. J. INT'L L. 1053 (2002); Symposium: The ILC's State Responsibility Articles, 96 AJIL 773 (2002).

${ }^{15}$ Cf. Theodor Meron, International Law in the Age of Human Rights, 301 R.C.A.D.I. 10 (2003), with MARTTI Koskenniemi, International Law and the Far Right: Reflections on Law and Cynicism (2019); Tom Ginsburg, Authoritarian International Law?, 114 AJIL 221 (2020). 
number of decisions of international courts, tribunals and other bodies refer to the articles."16 Indeed, 163 decisions by international tribunals between 2001 and 2016 referred to the ILC Articles, ${ }^{17}$ with a further eighty-six cases by early $2019,{ }^{18}$ and further more since then. ${ }^{19}$ Not every actor agrees with everything, ${ }^{20}$ as shown by criticisms in the Sixth Committee's 2019 session of erga omnes claims by China and $\operatorname{Iran}^{21}$ and of the silence on special circumstances of small island developing states by Micronesia. ${ }^{22}$ But the arc of the legal process bends toward positivizing the ILC work. ${ }^{23}$ To take the example of American Journal of International Law authors, the most insightful critic of the ILC's project nonetheless applied it with only slight hesitation as an arbitrator, ${ }^{24}$ and the sharpest argument against a particular rule had no effect on state and judicial practice. ${ }^{25}$

There are three reasons why a qualified challenge of the continuation of current practice is more than contrarianism. First, the Pandemic is peculiar in its universal, immediate, grave, and broadly shared character. This increases the likelihood that much practice will emerge ("widespread") from a variety of actors ("representative") and will be broadly similar ("consistent"), thus making it "general" in the technical sense required to identify custom. ${ }^{26}$ Secondly, many of the rules likely to come under pressure are based not on consolidated practice but inferences from general principles, systemic logic, and tolerance by states. It is not a criticism of the ILC Articles—most alternatives proposed are even more problematic. ${ }^{27}$ But rules of this sort, an excellent recipe for gradual adoption in state and judicial practice in normal times, ${ }^{28}$ are vulnerable to being superseded by concerted spurts of contrary practice in extraordinary ones. The third point relates to the forum. Every three years, most recently in

${ }^{16}$ GA Res. 74/180, paras. 1, 4 (Dec. 18, 2019).

${ }^{17}$ UNSG, Responsibility of States for internationally wrongful acts: Compilation of decisions of international courts, tribunals and other bodies, paras. 5-6, UN Doc. 71/80/Add.1 (June 20, 2017).

${ }^{18}$ UNSG, Responsibility of States for internationally wrongful acts: Compilation of decisions of international courts, tribunals and other bodies, para. 5, UN Doc. 74/83 (Apr. 23, 2019).

${ }^{19}$ E.g. Application of the International Convention for the Suppression of the Financing of Terrorism and of the International Convention on the Elimination of All Forms of Racial Discrimination (Ukraine v. Russia), para. 29 (Int'l Ct. Just. Nov. 8, 2019); The Duzgit Integrity Arbitration (Malta v. São Tomé and Príncipe), PCA Case No. 2014-07, paras. 204, 212 (Dec. 18, 2019) [hereinafter Duzgit Integrity]; Panel Report, Saudi ArabiaMeasures Concerning the Protection of Intellectual Property Rights, paras. 7.50, 7.51, 7.161, WTO Doc. WT/DS567/R (circulated June 16, 2020) [hereinafter Saudi Arabia_IP Rights].

${ }^{20}$ Federica Paddeu, To Convene or Not to Convene? The Future Status of the Articles on State Responsibility: Recent Developments, 21 Max Planck Y.B. InT'L L. 83, 101-07 (2017). For polite caution, see Sixth Committee, Summary Record of 13th Meeting (Oct. 15, 2019), paras. 20 (UK), 56 (Israel), UN Doc. A./C.6/74/SR.13 (Feb. 28, 2020).

${ }^{21} \mathrm{Id}$., paras. $17,58$.

${ }^{22} I d$., para. 66.

${ }^{23}$ Supra notes 17-18. On erga omnes, Application of the Convention on the Prevention and Punishment of the Crime of Genocide (Gam. v. Myan.), para. 41, (Int'l Ct. Just. Jan. 23, 2020) [hereinafter Myanmar Genocide].

${ }^{24}$ Cf. David D. Caron, The ILC Articles on State Responsibility: The Paradoxical Relationship Between Form and Authority, 96 AJIL 857 (2002); Cargill, Incorporated v. Mexico, ICSID Additional Facility Case No. ARB(AF)/05/2, paras. 381-82, 420 (Sept. 18, 2009).

${ }^{25}$ Cf. Sloane, supra note 13; Compilation 2019, supra note 18, at 25-27.

${ }^{26}$ Int'l L. Comm'n, Conclusions on identification of customary international law, Conclusion 8(1), UN Doc. A/73/10 (2018) 119. Cf. the plausible expectation of consistency with tension between investment-importing and exporting, or coastal and flag states. Id., Commentary 4.

${ }^{27}$ EDF International SA and Ors v. Argentina, ICSID Case No. ARB/03/23, para. 319 (Feb. 5, 2016).

${ }^{28}$ Compilation 2019, supra note 18. 
2019, the General Assembly considers the future of the ILC Articles. States are at a stalemate, ${ }^{29}$ and there are good reasons for arguing against treatification, ${ }^{30}$ beyond the pragmatic suspicion about multilateral treaty fatigue. ${ }^{31}$ But the decision "to further examine . . the question of a convention on responsibility of States for internationally wrongful acts or other appropriate action on the basis of the articles" in 2022 provides states with a deadline for reflecting on whether to become more assertive as lawmakers and adjust the law of responsibility to the (post-)Pandemic world. ${ }^{32}$

\section{The Future of Communitarian State Responsibility}

Discussion of communitarianism is complicated by the fuzziness of the legal and sociological concepts employed. ${ }^{33}$ "It is not easy to establish when an interest acquires the dimension of a general interest," 34 particularly when it is furthered through classically bilateral rules. ${ }^{35}$ Broadly, however, the communitarian perspective relates to legal rules that move beyond the model of a relationship solely between the injured and responsible state, ${ }^{36}$ conceptualized in traditional tort law terms of rectification of wrongful violation of private rights. ${ }^{37}$ This Part will consider four areas of state responsibility where a communitarian shift would go with the systemic grain.

First, the basis of responsibility seems agnostic on bilateralism and multilateralism. It is trite law nowadays that responsibility arises out of an internationally wrongful act. ${ }^{38}$ But the historical move "from Anzilloti to Ago"39 in the conceptualization of responsibility as based on breach, rather than injury, ${ }^{40}$ was communitarian in its revolutionary implications. ${ }^{41}$ The perspective shifted from the bilateralist focus on the injured (injury/damage) or responsible (fault) actors to the community interest in compliance with even bilateral obligations. ${ }^{42}$ Thorny questions of whether parties to multilateral obligations and nonstate

29 Sixth Committee, Summary Record of 34th Meeting (Nov. 11, 2019), paras. 13-21, UN Doc. A./C.6/74/SR.34 (Nov. 29, 2019).

${ }^{30}$ Paddeu, To Convene or Not to Convene?, supra note 20, at 120-23.

${ }^{31}$ Joost Pauwelyn, Ramses A. Wessel \& Jan Wouters, When Structures Become Shackles: Stagnation and Dynamics in International Lawmaking, 25 EUR. J. INT'L L. 733 (2014).

${ }^{32}$ GA Res. 74/180, supra note 16, para. 9.

${ }^{33}$ Cf. Simma, supra note 9, at 233-36; Crawford, Multilateral Rights, supra note 10; Gleider I. Hernández, A Reluctant Guardian: The International Court of Justice and the Concept of "International Community," 83 BRIT. Y.B. INT'L L. 13 (2013).

${ }^{34}$ Gaja, supra note 12 , at 21.

${ }^{35}$ Villalpando, The Legal Dimension, supra note 12, at 395.

${ }^{36}$ See Barcelona Traction, Light and Power Company, Limited (Belg. v. Spain), 1970 ICJ Rep. 3, para. 33 (Feb.

5) (obligations erga omnes elaborated by contrast with bilateralist investment protection).

${ }^{37}$ John Gardner, What Is Tort Law for? Part 1. The Place of Corrective Justice, 30 L. \& PHIL. 1 (2011).

38 ILC Articles, supra note 13, Art. 2, pt. 1, chs. II-III; Legal Consequences of the Separation of the Chagos Archipelagos from Mauritius in 1965, Advisory Opinion, 2019 ICJ Rep. 95, para. 77 (Feb. 25).

${ }^{39}$ Georg Nolte, From Dionisio Anzilotti to Roberto Ago: The Classical International Law of State Responsibility and the Traditional Primacy of a Bilateral Conception of Inter-state Relations, 13 EUR. J. INT'L L. 1083 (2002).

${ }^{40}$ James Crawford, State Responsibility: The General Part 54-60 (2013).

${ }^{41}$ Alain Pellet, Remarques sur une révolution inachevée-Le projet de la C.D.I. sur la responsabilité des États, 42 Annuaire Français de Droit International 7, 10-13 (1996).

${ }^{42}$ Eric Wyler, From "State Crime" to Responsibility for "Serious Breaches of Obligations Under Peremptory Norms of General International Law," 13 EUR. J. INT'L L. 1147, 1153 (2002). 
beneficiaries are "injured" by the breach were cleverly sidestepped, leaving space for developing communitarian primary rules involving diverse actors. The routine and widespread invocation of responsibility in relation to the Pandemic, including in respect of such obligations implicating the general interest as human rights, reinforces the openness of international law toward its communitarian potential.

The second stratum of rules relates to shared responsibility. Rules on attribution by acknowledgment and invocation in cases of plurality of responsible actors may address to some extent the allocation of shared responsibility in relation to the Pandemic. ${ }^{43}$ But many claims will turn on rules regarding aid or assistance between different actors, currently expressed in custom-reflecting terms in Article 16 of the ILC Articles:

A State which aids or assists another State in the commission of an internationally wrongful act by the latter is internationally responsible for doing so if: (a) that State does so with knowledge of the circumstances of the internationally wrongful act; and (b) the act would be internationally wrongful if committed by that State. ${ }^{44}$

Article 16 and the analogous rule in the ILC work on responsibility of international organizations, ${ }^{45}$ both based to a significant extent on inferences from sparse and peculiar practice, may be challenged on three points by the Pandemic. First, is there a requirement of fault on the part of the aiding actor? Article 16(a) speaks of "knowledge," and communitarian interests may either caution against a permissive standard that could discourage international cooperation or insist on the public good of maximizing opportunities for reparation to injured actors, a scarce resource in the patchily judicialized international order. ${ }^{46}$ Secondly, is the double-obligation requirement in Article 16(b) correct and desirable? Some doubt it, ${ }^{47}$ and the involvement in Pandemic-related claims of states bound by different regional instruments and by international organizations, rarely bound by the same obligations as states (e.g., to prevent the use of one's territory or not to act outside the organization's competence), is likely to generate practice challenging the rule. Thirdly, does the rule on aid apply to omissions, particularly failure to provide information? The apparently negative answer is likely to be challenged by claims alleging supportive omissions. ${ }^{48}$ In short, the law of shared responsibility complicates easy dichotomies between bilateralist and communitarian interests, although the remedial perspective lent by the Pandemic is likely to favor the general interest in maximizing the opportunities for reparation. ${ }^{49}$

${ }^{43}$ ILC Articles, supra note 13, Arts. 11, 48. Governmental tweets are attributable as conduct of organs, thus retweets may count as acknowledgment, Saudi Arabia-IP Rights, supra note 19, para. 7.161.

${ }^{44}$ Application of the Convention on the Prevention and Punishment of the Crime of Genocide (Bosn. \& Herz. v. Serb. and Montenegro), 2007 ICJ Rep. 43, para. 420 (Feb. 26) [hereinafter Bosnia Genocide].

${ }^{45}$ Int'l L. Comm'n, Articles on responsibility of international organizations, II Y.B. INT'L L. Comm'N, pt. 2 (2011), Art. 14, UN Doc. A/CN.4/SER.A/2011/Add. 1 (Part 2) 40 [hereinafter 2011 ILC Articles].

${ }^{46}$ Vladyslav Lanovoy, Complicity in an Internationally Wrongful Act, in PrINCIPLES OF SHARED RESPONSIBILITY IN InTERnational LAW 134, 150-56 (André Nollkaemper \& Ilias Plakokefalos eds., 2014); JaCKSON, supra note 13, at $159-61$.

47 JACKSON, supra note 13 , at 162-71.

${ }^{48}$ Bosnia Genocide, supra note 44, paras. 420, 432.

${ }^{49}$ Anna van Aaken, Shared Responsibility in International Law: A Political Economy Analysis, in DisTRIBUTION OF Responsibility in International LaW 153, 160 (André Nollkaemper \& Dov Jacobs eds., 2015). 
The third body of rules pertains to the content of responsibility, and raises two issues of multilateral significance. The first is the legal relevance of the capacity of the responsible actor, be it a state or an international organization, to make reparation by full compensation. The ILC Articles address the concern "that the principle of full reparation may lead to disproportionate and even crippling requirements [for] the responsible State" and conclude that, in the context of compensation, it is addressed by the exclusion of indirect and remote damage- but, by necessary implication, not of "crippling" damage. ${ }^{50}$ Special Rapporteur James Crawford's claim that concerns over crippling compensation were exaggerated ${ }^{51}$ did not persuade everybody, ${ }^{52}$ and may seem even less attractive after recent multi-billion-dollar awards against developing states. ${ }^{53}$ Pandemic-related practice could seek to challenge the bilateralist focus on the interests of the injured actor in favor of the community interest in not crippling basic functions of states and international organizations. ${ }^{54}$ The second issue relates to aggravated responsibility for serious breaches of obligations under peremptory norms of general international law (jus cogens). ${ }^{55}$ The magnitude of the Pandemic and its impact on the life and health of individuals and the viability of organized polities suggests a possibility of creative application of the accepted rules on jus cogens. ${ }^{56}$ The obligation not to render assistance in the maintenance of situations created by serious breaches of jus cogens could be operationalized through international (non)cooperation, for example regarding actors spreading or not suppressing the Pandemic, and the obligation to cooperate through lawful means to bring an end to such breaches could at a minimum discourage efforts to undermine relevant international institutions. ${ }^{57}$

Implementation of responsibility raises the clearest multilateral issues. ${ }^{58}$ The uneven distribution of consent to adjudicators and the pragmatic unwillingness to articulate claims in sufficiently formalized terms against powerful states ${ }^{59}$ suggests that the scope of the right to invoke responsibility could be tested, particularly on points that are accepted in principle but rarely applied in practice. What makes a state "specially affected" for the purpose of

${ }^{50}$ ILC Articles, supra note 13, Art. 34, Commentary 5; also Art. 31(1); followed regarding international organizations, 2011 ILC Articles, supra note 45, Art. 31, Commentary 4, Art. 34, Commentary 1, Art. 40, Commentary 4.

${ }^{51}$ James Crawford, Third Report on State Responsibility, II Y.B. INT'L L. Comm'N, pt. 1, paras. 41-42, 162-64 (2000), UN Doc. A/CN.4/SER.A/2000/Add. 13.

52 II Y.B. INT'L L. CoMm’N, pt. 1, 95, para. 74 (2011), UN Doc. A/CN.4/SER.A/2011/Add. 1 (Part 1) (“[The World Health Organization] . . . criticised the principle [of full compensation because it] 'could lead to excessive exposure taking into account that international organizations in general do not generate their own financial resources."'); Duzgit Integrity, supra note 19, para. 26 (diss. op., Kateka, J.) ("The main concern [of some members of the ILC] was the potentially crippling effect of compensation payments [on the developing countries].”).

${ }^{53}$ ConoccoPhillips Petrozuata BV and Ors v. Venezuela, ICSID Case No. ARB/07/30 (Mar. 8, 2019); Tethyan Copper Company Pty Limited v. Pakistan, ICSID Case No. ARB/12/1 (July 12, 2019).

${ }^{54}$ Martins Paparinskis, A Case Against Crippling Compensation in International Law of State Responsibility, 83 MoD. L. Rev. (2020), available at https://doi.org/10.1111/1468-2230.12562.

55 ILC Articles, supra note 13, pt. 2, ch. III.

${ }^{56}$ E.g., right of self-determination, Int'l L. Commission, Draft conclusions on peremptory norms of general international law (jus cogens), Annex (h), Commentary 12, UN Doc. A/74/10 142 (2019) [hereinafter 2019 ILC Draft Conclusions].

57 ILC Articles, supra note 13, Art. 41; 2019 ILC Draft Conclusions, supra note 56, Conclusion 19, Commentaries 3-8; cf. Dire David Tladi, Third report on peremptory norms of general international law (jus cogens) (Feb. 12, 2018), paras. 86-102, 160 (Draft Conclusions 20-21), UN Doc. A/CN.4/714.

${ }^{58}$ Dupuy, supra note 12.

59 Obligations Concerning Negotiations Relating to Cessation of the Nuclear Arms Race and to Nuclear Disarmament (Marsh. Is. v. UK), 2016 ICJ Rep. 833, paras. 44-58 (Oct. 5) [hereinafter Obligations]. 
invocation of responsibility? ${ }^{60}$ Can states invoke responsibility when they are not injured ${ }^{61}$ and, if so, regarding which obligations? ${ }^{62}$ Can such states implement responsibility by means of so-called third-party countermeasures? ${ }^{33}$ The apparent strength of judicial support for various multilateral positions is not always echoed in state practice. Take, for example, the skeptical note struck by China in the Sixth Committee's 2019 session:

$[D]$ ifferences in interpretation and major concerns existed among States with respect to the provisions relating to serious breaches of obligations under peremptory norms of general international law, countermeasures and measures taken by States other than an injured State. ${ }^{64}$

A concerted effort to explicitly operationalize communitarian rules in the practice of the implementation of state responsibility would be an important development.

\section{The Future of Bilateralist State Responsibility}

It seems likely that the law of state responsibility will be pushed toward a reentrenchment of its bilateral underpinnings, attuned as they are to the interests of the injured state. This Part will consider three areas of state responsibility where a bilateralist shift would go with the systemic grain.

First, claims, particularly in judicial fora, are likely to raise questions about circumstances precluding wrongfulness such as force majeure, necessity, and distress. ${ }^{65}$ These circumstances will not be easy to invoke to defend conduct in breach of primary rules in practice, e.g., the "only available means" criterion for necessity in light of apparently very different approaches adopted by states. ${ }^{66} \mathrm{~A}$ critical reading of practice in support of the ILC Articles ${ }^{67}$ may suggest that impressive numbers are not always matched by the quality of reasoning, approval in state

${ }^{60}$ ILC Articles, supra note 13, Art. 42(b)(i); Obligations, supra note 59, para. 44.

${ }^{61}$ Questions Relating to the Obligation to Prosecute or Extradite (Belg. v. Sen.), 2012 ICJ Rep. 449, para. 68 [hereinafter Questions]; Myanmar Genocide, supra note 23, para. 41. But note the skepticism of judges with a professional background in the foreign service of certain states. Questions, at 481, paras. 10-22 (sep. op., Skotnikov, J.); Questions, at 571, paras. 2-23 (diss. op., Xue, J.); Questions, at 584, para. 11 (dec., Donoghue, J.); Obligations, supra note 60, at 1029, para. 8 (dec., Xue, J.); Myanmar Genocide, supra note 23, para. 8 (sep. op., Xue, V-P.).

${ }^{62}$ Cf. 2019 ILC Draft Conclusions, supra note 56, Conclusion 17(2) ("Any State is entitled to invoke the responsibility of another State for a breach of . . jus cogens."), with the only two examples of application in the International Court of Justice, to a particular criminal cooperation procedure: Questions, supra note 60, and perhaps the most-endorsed contemporary peremptory rule, Myanmar Genocide, supra note 23, Annex (b), Commentary 6.

${ }^{63}$ The ILC left the question open, ILC Articles, supra note 13, Art. 54; 2019 ILC Draft Conclusions, supra note 56, Conclusion 19(1), and while legal writings support such a right, MarTin Dawidowicz, Third-PARTY Countermeasures in International Law (2017), there is resistance in state practice, The Declaration of the Russian Federation and the People's Republic of China on the Promotion of International Law, para. 6 (June 25, 2016), available at https://www.mid.ru/en/foreign_policy/position_word_order/-/asset_publisher/ 6S4RuXfeYlKr/content/id/2331698; Declaration of the Russian Federation and Islamic Republic of Iran on the Promotion of International Law, UN Doc. A/74/930-S/2020/588, para. 9 (June 25, 2020).

${ }^{64}$ Supra note 20, para. 17, also para. 37 (Russia); id.

65 ILC Articles, supra note 13, Arts. 23-25.

66 See generally PADdeU, JustificAtion, supra note 13, ch. 8.

${ }^{67}$ Compilation 2019, supra note 18, at 25-27. 
and institutional practice, and representativity of the international community. ${ }^{68}$ Concerted practice could attempt to reshape, for example, the rule of necessity around the gravity-ofperil axis, or relax the "only available means" to "reasonable means," or relax or even drop altogether the qualification as to contribution. ${ }^{69}$ While in some specialist fields like investment law such a development could further the community interest in not beggaring actors in extraordinary circumstances, the broader systemic effect evokes Philip Allot's memorable warning of the danger posed to the international legal order by an expansive reading of necessity. ${ }^{70}$

Secondly, the weight of the argument on calculation and valuation of damages will be borne not by grand questions of principle but the boring small print of evidence, injury, causation, and damage. ${ }^{71}$ Black letter law calls only for reparation for damage for injury caused by the wrongful act. ${ }^{72}$ The law on the topic is still governed by the bilateralist assumptions of Factory at Chorzów "that reparation must, as far as possible, wipe out all the consequences of the illegal act and re-establish the situation which would, in all probability, have existed if that act had not been committed."73 State practice regarding the Pandemic is likely to test all the permutations of causality, clarifying uncertainties, fleshing out ambiguities through application, and generally reinforcing the classic bilateralist structure. At what point are different instances of conduct by states, international organizations, and nonstate actors, sometimes on their own, sometimes due to combined effect, too remote for a sufficient causal link? ${ }^{74}$ How is the principle of mitigation, dispositive to arguments about the technical incompetence of some injured states, applied? ${ }^{75}$ Is concurrency of factors causing damage irrelevant ${ }^{76}$ or relevant, and how can it be operationalized in practice? ${ }^{77}$ All these points are vague, unsettled, or both, and crucial for evaluating claims relating to the Pandemic. ${ }^{78}$

The final bilateralist element of state responsibility is international law at its most archaic, the dystopian schoolyard transposed internationally, namely countermeasures. ${ }^{79}$ Self-help plays to the strength of the more influential actors but puts even them "in the position of potentially being held responsible for violating international law" if they misjudge the situation or their response. The U.S. State Department's legal advisor was plainly right that

\footnotetext{
${ }^{68}$ Martins Paparinskis, Circumstances Precluding Wrongfulness in International Investment Law, 31 ICSID REV. 484, 497-99 (2016)

${ }^{69}$ ILC Articles, supra note 13, Art. 25.

${ }^{70}$ Philip Allot, State Responsibility and the Unmaking of International Law, 29 HARV. J. INT'L L. 1, 17-21(1988).

${ }^{71}$ Pey Casado v. Chile (II), ICSID Case No. ARB/98/2, para. 232 (Sept. 13, 2016).

72 ILC Articles, supra note 13, Art. 31, Commentaries 9-10.

${ }^{73}$ Factory at Chorzów (Ger. v. Pol.), 1928 PCIJ, Ser. A, No. 17, 29, 47 (Sept. 13). Cf. Arthur Ripstein, As if It Never Happened, 48 WM. \& Mary L. Rev. 1957 (2007); Gardner, supra note 37.

${ }^{74}$ ILC Articles, supra note 13, Art. 31, Commentary 10.

75 Id., Commentary 11; Iran v. U.S., Award No. 604-A15 (II:A)/A26 (IV)/B43-FT, paras. 1796-99 (Full Tribunal Iran-U.S. Claims Tribunal Mar. 10, 2020).

${ }^{76}$ Id., Commentaries 12-13; Molla Sali v. Greece, App. No. 20452/14, Joint Partly Dissenting Opinion, paras. 47-49 (Eur. Ct. Hum. Rts. June 18, 2020, Lemmens, Koskelo, and Eicke, JJ.).

${ }^{77}$ Certain Activities Carried Out by Nicaragua in the Border Area (Costa Rica v. Nicar.), 2018 ICJ Rep. 15, para. 31 (Feb. 20).

${ }^{78}$ It is less obvious that contribution to injury is particularly relevant to claims regarding the spread of the Pandemic. ILC Articles, supra note 13, Art. 39; Duzgit Integrity, supra note 19, paras. 197-99.

${ }^{79}$ Allot, supra note 70 , at 22-24.
} 
"countermeasures should not be engaged in lightly." 80 The Pandemic will provide an opportunity for relevant actors to express their views on whether the ILC Articles accurately capture the law of countermeasures, or are either too strict or too permissive. ${ }^{81}$ Reactions to claims by the United States will carry particular weight because its position is largely in line with the substantive conditions in the ILC Articles, although less so with the procedural ones. ${ }^{82}$ Overall, the mood music of these times is withdrawal from international law. It is only to be expected that, with the breakdown of communitarian institutions of enforcement and implementation, the classic fallback of self-help will come once more to the fore. ${ }^{83}$

\section{Conclusion}

Will the Pandemic affect the balance of the delicately intertwined bilateral and communitarian elements in the law of state responsibility? ${ }^{84}$ For some, the apparent dysfunction of international politics makes everyone a Westphalian in the Pandemic, ${ }^{85}$ with reentrenched bilateralism filling the gap of the apparent failure by institutionalized communitarianism. ${ }^{86}$ For others, the egoism of some polities may be leading observers to underestimate communitarianism beyond institutional frameworks, a development on the desirability of which reasonable people will disagree. ${ }^{87}$

This Essay first argued for the presence of a normative and institutional window for a significant change in the law (Part II). It then considered possible developments in the communitarian (III) and bilateralist directions (IV), concluding that each is consistent with a different aspect of the systemic grain. Of course, to suggest that established rules may be challenged is not exceptional. The international legal process normally operates through gradual change. ${ }^{88}$ But in a different sense, exceptional is precisely what the situation is. The gravity and immediacy of the Pandemic, the likely generality of state practice, and the completeness of possible challenges to the current rules, taken together, constitute a lawmaking moment inconceivable just nine months ago, giving the international community until autumn 2022 to decide whether the law of the ILC Articles is fit for the (post-)Pandemic world. ${ }^{89}$

\footnotetext{
${ }^{80}$ Brian Egan, Remarks on International Law and Stability in Cyberspace (Nov. 10, 2016), in DigEST OF UNITED States Practice in International Law 2016, at 815, 822 (CarrieLyn D. Guymon ed., 2017).

${ }^{81}$ Cf. Appeal Relating to the Jurisdiction of the ICAO Council Under Article 84 of the Convention on International Civil Aviation (Bahr. and Ors v. Qatar), para. 49, (Int'l Ct. Justice July 14, 2020); id. (sep. op., Cançado Trindade, J.).

${ }^{82}$ Cf. Egan, supra note 80; ILC Articles, supra note 13, Arts. 49-53, particularly 50, 52(1)(b), (3)(b).

${ }^{83}$ Bruno Simma \& Dirk Pulkowski, Of Planets and the Universe: Self-Contained Regimes in International Law, 17 EUR. J. INT'L L. 483 (2006).

${ }^{84}$ Lewis Carroll, The Hunting of the Snark (1876) ("for the Snark was a Boojum, you see") (emphasis in the original).

${ }_{85}$ Maurice Mendelson, International Law in the Past Half-Century - And the Next?, 50 CURRENT L. Probs. 421, 438 (1997).

${ }^{86}$ UN Press Release, COVID-19 Fast Becoming Protection Crisis, Guterres Warns Security Council (July 2, 2020), at https://news.un.org/en/story/2020/07/1067632.

${ }^{87}$ Cf. Martti Koskenniemi, Solidarity Measures: State Responsibility as the New International Order?, 72 BrIT. Y.B. InT'L L. 337 (2001); James Crawford, Chance, Order, Change: The Course of International Law, 365 R.C.A.D.I. 19, ch. 8 (2013).

${ }^{88}$ Crawford, supra note 87 , at $21-22$.

${ }^{89}$ GA Res. $74 / 180$, supra note 16 , para. 9.
} 